\title{
A systematic literature review about the level of digital competences defined by DigCompEdu in higher education
}

\author{
Eider Bilbao-Aiastui \\ Universidad de Deusto, Bilbao, España \\ mail: eiderbilbaolapendeusto.es \\ ORCID: https://orcid.org/0000-0002-7928-4303
}

\section{Arantza Arruti}

Universidad de Deusto, Bilbao, España

mail: aarrutidadeusto.es

ORCID: https://orcid.org/0000-0001-8334-3831

\author{
Roberto Carballedo Morillo \\ Universidad de Deusto, Bilbao, España \\ mail: roberto.carballedodedeusto.es \\ ORCID: https://orcid.org/0000-0001-6709-1865
}

\begin{abstract}
Nowadays, we are facing a historical moment in which education practices are being transformed-mainly due to the increase of technologies and their massive use at all levels of society; thus, it is necessary to integrate them in educational settings. In this context, the aim of this paper is to analyse the level of technological competences of university professors. To this end, a systematic literature review based on the PRISMA methodology is carried out. The search was focused on WoS and SCOPUS databases. Initially, 815 documents were retrieved, and after applying the exclusion criteria 30 papers were selected. The selected papers have been analysed in detail and the final conclusions have been structured according to the DigCompEdu digital competence framework. The results show that the level of Digital Competences of University Professors (DCUP) is moderate, and highlight aspects to improve: Reflective Practice is not cited in any article, and Learner's Empowerment and Facilitating Students' Digital Competence are the least referred. These aspects should be considered for future research and, for this reason, it is recommended to carry out continuous training for university professors supported by the DigCompEdu framework.
\end{abstract}

Keywords: DigCompEdu, digital competences, higher education, technological competences, university professors.

\section{Una revisión sistemática de la literatura sobre el nivel de competencias digitales definidas por DigCompEdu en la educación superior}

\section{RESUMEN}

Actualmente nos encontramos ante un momento histórico en el que las prácticas educativas se están transformando, debido principalmente al incremento de las tecnologías y su uso masivo en todos los niveles de la sociedad, por lo que es necesario integrarlas en los contextos educativos. En este contexto, el objetivo de este trabajo es analizar el nivel de competencias tecnológicas de los profesores universitarios. Para ello, se realiza una revisión sistemática basada en la metodología PRISMA. La búsqueda se centró en las bases de datos WoS y SCOPUS. Inicialmente se recuperaron 815 documentos y tras aplicar los criterios de exclusión se seleccionaron 30 trabajos. Los documentos seleccionados se han analizado en detalle y las conclusiones finales se han estructurado según el marco de competencias digitales DigCompEdu. Los resultados muestran que el nivel de Competencias Digitales del Profesorado Universitario (CDPU) es moderado y destacan aspectos a mejorar: la Práctica Reflexiva no es citada en ningún artículo y Empoderar a los Estudiantes y Facilitar la Competencia Digital de los Estudiantes son los menos referidos. Estos aspectos han de tenerse en cuenta para futuras investigaciones y, por este motivo, se recomienda fomentar la formación continua avalados por el marco DigCompEdu.

Palabras Clave: Competencias digitales, competencias tecnológicas, DigCompEdu, educación superior, profesorado universitario.

ISSN: 0210-2773

DOI: https://doi.org/10.17811/rifie.50.4.2021.841-850 


\section{Introduction}

Today's society is heading towards the Fourth Industrial Revolution where citizens need digital skills for their professional functions (Brugia \& Zukersteinova, 2019). Therefore, Cabero-Almenara, and Palacios-Rodríguez (2020) stress that it is essential to obtain a digitally literate and competent society.

As a result, technologies have brought about a revolution in all areas and sectors of society, currently considered as the Information and Knowledge Society. One of them is the education field, in which technological training is a competence that must be developed by university professors.

According to the National Institute of Educational Technologies and Teacher Training (INTEF, 2017) technological competences can be defined as the creative, critical and safe use of information and communication technologies to achieve goals related to work, employability, learning, leisure, inclusion and participation in society.

Considering the need for a digitally competent European society, Ferrari leads the DigComp project of the Joint Research Centre of the European Commission, which defines the framework of digital competences for citizenship (Ferrari, 2012, 2013). This framework, published in 2013 and revised in 2016 and 2017 (Caena \& Redecker, 2019), results in the European Digital Competence Framework for Teachers, commonly known as DigCompEdu (Redecker \& Punie, 2017). Its aim is to promote the development of teachers' digital competence and to promote innovation in European education. In fact, this framework is crucial for this systematic review. It is the basis for guiding the discussion and organising the conclusions of the work described in this paper (Redecker \& Punie, 2017).

Additionally, it is considered that teachers should develop pedagogical practices that allow them to improve their Digital Competences (DC). Cabero-Almenara \& Llorente-Cejudo (2020) emphasise that pedagogical competences must be acquired in order to know how to work intellectually with technologies, in enquiry, personal research, message creation and construction of knowledge.

This requires techno-pedagogical training, suitable for their educational level and research programs (Izquierdo et al., 2017). In this sense, Heitinka et al. (2016) state that it is important to develop the technological competences of teachers and to promote their training, in order to improve teaching and learning processes with Information and Communication Technologies (ICT).

The Council of the European Union (2003) also stresses the need for lifelong training in digital technology. Furthermore, several authors highlight the need for continuous training of university professors through workshops, courses, conferences, online symposia, etc. Therefore, it is essential to create a permanent support service for university lecturers (Alexander et al., 2019; Arruti et al., 2020; Cabero-Almenara \& Llorende-Cejudo, 2020; Ramírez-Montoya, 2020).

Cabero-Almenara et al. (2020) go further and highlight the need to carry out personalised lecturer training plans that enable university professors to reach advanced levels of competence, such as those focused on innovation and pedagogical leadership with ICT.

Universities have a great challenge to change the old educational paradigm. The effective integration of technological competences in their teaching and learning processes are fundamental (Amador et al., 2017; Levis, 2011; Rengifo-Millan, 2015).

Due to this situation, as indicated by Gómez (2017), the Conference of Rectors of Spanish Universities (CRUE) establishes among its objectives the duty to provide support and introduce new technologies to aid lecturers. Likewise, it emphasises the growth of WIFI connections, as well as the university students connecting to the university network.

In view of the above, there is a need to work on the DCUP, taking into account that the appropriate use of technologies could strengthen the use of new digital resources, interdisciplinarity and teaching innovation.

However, INTEF (2017) indicates that technological competences have been poorly developed, as there was no common frame of reference. The authors insist on the need to help lecturers to develop this DC in order to implement it correctly during their lessons.

Subsequently, the systematic review will be analysed in terms of technological competences of university professors. The next section describes the methodological aspects of the systematic review of the literature performed, and the third one shows the analysis of the selected articles. The paper ends with the discussion section and conclusion obtained.

\section{Method}

Research is carried out through systematic review, which is an ideal mechanism to find needs in society and thus opening up new lines for future research (Evans \& Benefield, 2001).

This paper follows the methodology of the systematic review (Gough et al., 2013). It is a methodology developed by Evidence for Policy and Practice Information Centre (EPPI) at the University College of London (UCL) Institute of Education, which consists of the following nine phases: review question, inclusion-exclusion criteria, search strategy, selection methodology, search results, data extraction processes, quality assessment and methodological rigour, and synthesis and conclusion (Gough, 2007).

The recommendations of Preferred Reporting Items for Systematic Reviews and Meta-Analyses (PRISMA), aimed at education, have also been taken into account to provide transparency, validation, objectivity and updating of this study (Moher et al., 2009).

As Bearman et al. (2012) point out, the limited use of systematic review within the field of higher education is an interesting phenomenon, as it is a methodology that is well used in other sectors of educational research.

This study is a systematic review of a formative nature, as it uses qualitative information to generate and explore a theory (Gough et al., 2012). Likewise, following the indications of Chalmers et al. (1987) the peer-reviewed articles are the most reliable, this research has provided with this recommendation.

\section{Search strategy}

The aim of the present study is to provide a systematic literature review, analysing the evidence given by the literature on the level of technological competences in university professors. Bearing in mind this objective, the following question is defined by Patient or Problem, Intervention, Comparison, Outcome and Time (PICOT):

- What is the technological competence level of university professor?

In this systematic literature review, only papers published in indexed journals in the area of education or information and communication technologies have been analysed. The study described in this paper takes as its starting date the year 2015. The reason for this choice is twofold: on the one hand, in that year, 
United Nations Educational, Scientific and Cultural Organisation (UNESCO, 2015) highlighted the relevance of the technological competence of the teachers in order to achieve the 2030 education goals; and on the other hand, in 2015 the European Commission defined the first proposal for the technological competence of the educators (the origin of DigComEdu). In addition, the deadline for publication of articles is 29 February 2020.
According to Ferreira and Morán (2011), in this study, Web of Science (WoS) and SCOPUS databases were used. Both have an impact factor on publications: Joint Citation Reports (JCR) and Scimago Journal and Country Rank (SJR).

Table 1

Keywords used in the systematic literature review

\begin{tabular}{llll}
\hline Technological competence & Technological competences & Technological competency & Technological competencies \\
\hline ICT competence & ICT competences & ICT competency & ICT competencies \\
\hline Teacher & Lecturer & Professor & \\
\hline Higher Education & Teaching & & \\
\hline
\end{tabular}

Morales and Aguado (2010), for their part, stress the importance of SCOPUS, the most widely used tool in Europe, linked to 435 million scientific websites. Also of great relevance is the fact that it is continuously used by universities and different international organisations. Table 1 shows the different keywords, both in English and Spanish, used in this systematic literature review.

\section{Selection process}

The first part of the search resulted in a total of 815 articles from indexed journals: 448 published in the WoS database and 367 in SCOPUS.
After eliminating duplicate papers, the first step of the systematic literature review focused on analysing the abstract of each document.

Once examining the articles independently, the most relevant information was extracted and included in a spreadsheet: (a) characteristics of the study, (b) population and (c) type of study. Once the articles were examined in depth according to the inclusion and exclusion criteria, a screening was carried out for the final selection of the studies. Thus, a total of 30 articles were finally selected for analysis (Figure 1).

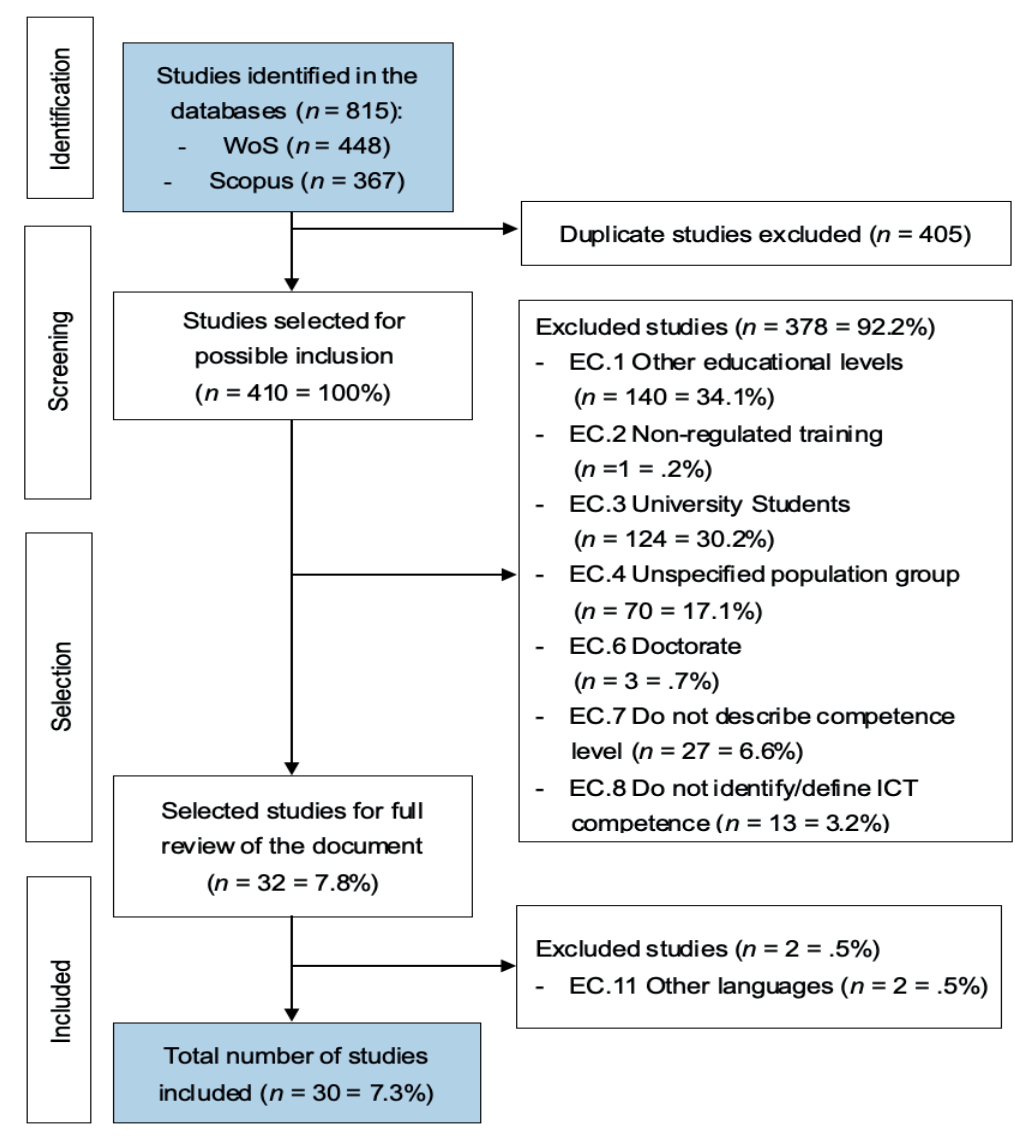

Figure 1. Flowchart of study selection procedure according to PRISMA 


\section{Data analysis}

To carry out the analysis of the selected articles, a checklist was developed to systematise the most relevant information. The objectives were: compile the characteristics of the studies, extract positive aspects, improve the technological competences, inform to evaluate the risk of bias, and open future lines of research.

After analysing the studies independently through the checklist, each selected article was studied in depth (Figure 1). First, the data were categorised using an inductive method. Secondly, their analysis was compared in order to reach a consensus and to report on the main results of the systematic literature review. All of it was done considering the technological competences of the DigCompEdu (Redecker \& Punie, 2017).

\section{Analysis of the selected articles}

The analysis of the 30 articles underlines the importance of technological competences in the university environment as facilitators and promoters of an improvement in the teaching-learning processes.

In fact, all the articles reviewed are contextualised in the university environment. In Table 2 we can see the geographical area of the articles.

Table 2

Geographical area of the articles

\begin{tabular}{ll}
\hline Africa $(n=1-3,3 \%)$ & Nigeria (1) \\
\hline Asia $(n=3-10 \%)$ & China (1), Indonesia (1), Thailand (1) \\
\hline Europe $(n=11-36,7 \%)$ & Spain (4), Russia (3), Turkey (2), Portugal (1), Ukraine (1) \\
\hline South America $(n=15-50 \%)$ & Colombia (7), Argentina (2), Costa Rica (2), Dominican Republic (2), Chile (1), Venezuela (1) \\
\hline
\end{tabular}

The ideas are grouped into the six competence areas defined by DigCompEdu: professional engagement (focused on the professional environment), digital resources (sources of creation and distribution of digital resources), teaching and learning (how to manage and orchestrate the use of digital tools in teaching and learning processes), assessment (digital tools and strategies to improve assessment), empowering learners (use of digital tools to empower students) and facilitating learners' digital competence (how to facilitate student digital competence).

As far as professional engagement is concerned, eight studies (Ardıç \& Çiftçi, 2019; Barrera et al., 2018; Barrios et al., 2018; Barroso et al., 2019; Mirabal et al., 2015; Montoya \& González, 2019; Montoya et al., 2018; Nakaznyi et al., 2016), emphasise the insufficient use of bibliographic managers, which highlights the lack of creation and publication of their own personal libraries, such as, RefWorks, Mendeley, Zotero, etc.

Other eleven works (Barrera et al., 2018; Barrios et al., 2018; Barroso et al., 2019; Mirabal et al., 2015; Montoya \& González, 2019; Montoya et al., 2018; Nakaznyi et al., 2016; Sysoyev \& Evstigneev, 2015; Ríos et al., 2018; Ventayen, 2019; Viloria et al., 2018) stress the importance of using bibliographic managers, databases, cloud storage, digital repositories, etc., as well as sharing them to encourage creation through cooperation and collaboration.

Twelve papers (Barrera et al., 2018; Barroso et al., 2019; Mirabal et al., 2015; Montoya et al., 2018; Ventayen, 2019; Viloria et al., 2018; Bossolasco \& Chiecher, 2015; Habibi et al, 2019; Noskova et al, 2019; Rodríguez \& Del Carmen, 2019; Tobar, 2017; Suarez-Carballo, 2020) mention that digital resources are used to communicate with other lecturers and thus share information, experiences, concerns and so on. Among these tools are forums, virtual debates and blogs that are highly valued by the university teaching community.

Three articles (Ardıç \& Çiftçi, 2019; Barrios et al., 2018; Ríos et al., 2018) indicate the lack of communication among lecturers to divulge information and generate knowledge.

Regarding computer security and protection, two studies (Barrios et al., 2018; Montoya et al., 2018), stress that new lecturers, those who are entering university teaching for the first time, have a higher level of knowledge than other university professors who have a very low level.
Ten studies (Ardıç \& Çiftçi, 2019; Barrios et al., 2018; Bossolasco \& Chiecher, 2015, Montoya \& González, 2019; Montoya et al., 2018; Rodríguez \& Del Carmen, 2019; Ríos et al., 2018; Suarez-Carballo, 2020; Tobar, 2017; Ventayen, 2019;) comment that lecturers have a good level of hardware and software as they have a broad knowledge of the tools and the role of technological competences.

With regard to the area of digital resources, seven works should be highlighted (Ardıç \& Çiftçi, 2019; Habibi et al., 2019; Mirabal et al., 2015; Montoya \& González, 2019; Montoya et al., 2018; Ríos et al., 2018; Ventayen, 2019), which indicate that university professors have a high level of competence in searching information and organising themselves using different online information sources. Eight studies point out that lecturers use other tools, programs and applications to collect or divulge the necessary information, such as Kahoot, Wix and similar (Barrera et al., 2018; Barroso et al., 2019; Habibi et al., 2019; Mirabal et al., 2015; Montoya \& González, 2019; Montoya et al., 2018; Ríos et al., 2018; Ventayen, 2019)

Concerning the third area, teaching and learning, some studies highlight the use by lecturers of the implementation of digital resources, with the consequent improvement of their strategies in the teaching-learning processes. According to nine studies, the most widely used resource is Moodle platform, which is closely followed by Virtual Campus, a teaching support platform (Barrera et al., 2018; Barroso et al., 2019; Grinsztajn et al., 2019; Hidalgo-Durán, 2019; Mirabal et al., 2015; Montoya \& González, 2019; Nakaznyi et al., 2016; Noskova et al., 2019; Ventayen, 2019).

Thirteen are the studies that promote different learning techniques and methodologies to improve the teaching of educational processes that encourage the use of technological competences, among others, techniques for collaborative learning, cooperative learning, project learning, problem-based learning, debates, and self-management (Barrios et al., 2018; Barroso et al., 2019; Bossolasco \& Chiecher, 2015; Habibi et al, 2019; Montoya \& González, 2019; Montoya et al., 2018; Nakaznyi et al., 2016; Noskova et al, 2019; Petelin et al., 2019; Ríos et al., 2018; Rodríguez \& Del Carmen, 2019; Sandí \& Sanz, 2020; Viloria et al., 2018).

These studies are aligned with four other studies (Ardıç \& Çiftçi, 2019; Nakaznyi et al., 2016; Noskova et al., 2019; Tobar, 2017), which state that there is a need for the integration of tech- 
nological competences by lecturers, since they present a low level of development in educational management based on technological competences. In other words, the aim is to include DC among the roles of university professors.

Alternatively, in seven works (Barrios et al., 2018; Barroso et al., 2019; Habibi et al., 2019; Noskova et al., 2019; Adisa et al., 2018; Dieguez, 2020; Lyubashits et al., 2016), it is underlined that there is a low knowledge about strategies or methodological tools among university professors, as well as the necessary competences for the creation and use of digital resources such as WebQuest, Flipped Classrooms, blended learning or Mobile learning.

With regard to assessment, nine studies (Barroso et al., 2019; Bossolasco \& Chiecher, 2015; Habibi et al., 2019; Henning et al., 2016; Montoya \& González, 2019; Montoya et al., 2018; Noskova et al., 2019; Ventayen, 2019; Viloria et al., 2018) reflect the potential of technological competences to maximise the benefits of assessment and feedback to lecturers and students. In addition, four studies (Barroso et al., 2019; Bossolasco \& Chiecher, 2015; Habibi et al., 2019; Montoya et al., 2018) confirm the effectiveness of assessments using technological competences to evaluate students in a formative and summative way.

Additionally, five studies (Adisa et al., 2018; Ardıç \& Çiftçi, 2019; Bossolasco \& Chiecher, 2015; Ríos et al., 2018; Ventayen, 2019) emphasise that some university professors evaluate their teaching practices with the use of technological competences while others have low-to-medium level of self-evaluation.

In terms of the fifth area about learner's empowerment, seven papers (Barrios et al., 2018; Barroso et al., 2019; Bossolasco \& Chiecher, 2015; Habibi et al., 2019; Montoya \& González, 2019; Noskova et al., 2019; Rodríguez \& Del Carmen, 2019) argue that through these tools university professors manage their time, having greater flexibility and thus capturing the attention of students and getting them more involved.

However, according to a study (Montoya et al., 2018), the lack of knowledge leads to a misuse of technological tools; and this generates discomfort in students since it affects the sequence and rhythm of the sessions.

Finally, with regard to the last area entitled facilitating the digital competence of learners', three papers (Ardıç \& Çiftçi, 2019; Barrera et al., 2018; Mirabal et al., 2015) highlight the knowledge of university professors of creative commons licenses and similar, as well as the processing of data directly linked to the field of research.

Other two studies (Tobar, 2017 Viloria et al., 2018) gather evidence confirming that the type of activities that use technological competences facilitate access to information in a short period of time and consequently, further develop research competence.

\section{Discussion}

In this section, the results related to the research question are discussed. The main conclusions are grouped into the six areas of DigCompEdu presented above.

Considering the first competence area, two studies (Barrios et al., 2018; Montoya et al., 2018) indicate the correlation between age and the ability to learn technological competences, so it seems that nobel university professors are more competent to learn or know more about these areas. Likewise, several authors find a relationship between age and the use of technological competences, with young people using technologies more and internalising these tools earlier (Cabero-Almenara et al., 2021; Claro et al., 2018; Inan \& Lowther, 2010; Solis de Ovando \& Jara, 2019). In contrast, some studies have shown that age is not a sig- nificant factor for teachers' digital competence, emphasising that many young university professors do not use technology productively (Cabero-Almenara et al., 2021; Fraile et al., 2018; Lucas et al., 2021).

As for the second competence area, eight papers, (Aslan \& Zhu, 2015; Ardıç \& Çiftçi, 2019; Habibi et al., 2019; Mirabal et al., 2015; Montoya \& González, 2019; Montoya et al., 2018; Ríos et al., 2018; Ventayen, 2019) indicate that university professors encourage the use of different sources of information and organise them through digital resources to collect or divulge the necessary information.

Similarly, different authors highlight the importance of organising, sharing and publishing digital resources (Claro et al., 2018; Redecker \& Punie, 2017). Therefore, this competence contributes to promote more efficient learning (Castañeda \& Adell, 2013).

Regarding the third area, eighteen studies (Ardıç \& Çiftçi, 2019; Barrera et al., 2018; Barrios et al., 2018; Barroso et al., 2019; Bossolasco \& Chiecher, 2015; Cejas-León \& Navío, 2018; Habibi et al., 2019; Lyubashits et al., 2016; Mirabal et al., 2015; Montoya \& González, 2019; Nakaznyi et al., 2016; Noskova et al., 2019; Rodríguez \& Del Carmen, 2019; Tobar, 2017; Ríos et al., 2018; Ventayen, 2019; Viloria et al., 2018; Zhang \& Wang, 2019), the studies emphasise the low level of pedagogical skills and the importance of improving this aspects as opposed to technical ones, since university professors have a better knowledge of the last ones.

Reaffirming this idea, several authors emphasise the need to address pedagogical versus technological aspects, since teachers are more proficient in technical aspects than in didactic use (Cabero \& Barroso, 2016; Cabero-Almenara \& Llorente-Cejudo, 2020; Redecker \& Punie, 2017). This issue is closely related to the pedagogical training of higher education professors, which is often non-existent. As a result, Bond et al. (2018) stress that pedagogical training is crucial for adequate DCUP.

In relation to the fourth area, a striking aspect of the quality assessment process is the lack of evaluation of teaching-learning practices using technological competencies. Therefore, the low level of university professors in this area is emphasised. Similarly, the European Commission in DigCompEdu points out the importance of integrating digital tools in the process of formative evaluation (Redecker \& Punie, 2017), as the use DC in this area are almost non-existent.

The Corona Virus Disease (COVID-19) has accentuated the need for this competence in universities, as the risk of fraudulent practices in any assessment is high and higher in online assessment (Grande-de-Prado et al., 2021). For this reason, universities have the great challenge of fostering flexibility and creativity at this time to carry out an assessment that is continuous, varied, formative and that reduces or eliminates final tests (García-Peñalvo et al., 2020; González et al., 2020).

In relation to areas five and six, it should be stressed that there are few studies that report on them, therefore there is a low level of these competences among university professors. Furthermore, these findings are problematic, as these two competences are the only ones directed at the training of university students in terms of DC. Moreover, they are crucial for the successful integration of university students into the demands of the world of work, for example: active participation, inclusion of digital skills, responsible use of digital skills, problem solving, etc.

Today, the challenge for the University is to train competent professionals who can deal with the different situations that will face them in their professional practice.

Furthermore, the European Commission, in DigCompEdu, states the importance of acquiring these two competences to pro- 
mote the empowerment and facilitation of university students' DC (Redecker \& Punie, 2017).

\section{Conclusions}

After carrying out the systematic literature review and checking the results obtained, as far as the areas of DigCompEdu are concerned, two characteristics stand out. On the one hand, point 1.3 Reflective Practice is not cited in any article, so a lack is identified that should be taken into account, since several authors consider reflective competence as a key competence for teachers and for improving current teaching (Allas et al., 2017; Beauchamp, 2015; Kaçaniku et al., 2019; Lane et al., 2014; Liu, 2015; Parada \& Pluvinage, 2014; Pochulu et al., 2016).

Also, COVID-19 pandemic has accentuated the need for reflective practice in the university educational environment, to promote self-criticism and improve educational pedagogy with the use of technological tools, encouraging a true digital transformation (Cabero-Almenara \& Llorente-Cejudo, 2020; Cabero \& Valencia, 2020; García-Peñalvo \& Corell, 2020; García-Peñalvo et al., 2020; Ramírez-Montoya, 2020).

On the other hand, areas 5. Learner's Empowerment and 6. Facilitating Students' Digital Competence are the least referred, therefore there is an evident gap to be considered for future research in these areas. This gap may be due to the lack of DCUP, since if they do not have the DC fully incorporated, it will be difficult for them to provide these skills to their students.

Likewise, the systematic literature review underlines the relevance of the development of DCUP. It also confirms that university professors show a moderate level of technological competences, since these are continually being transformed and improved. This finding correlates with Cabero-Almenara et al. (2020) who highlight that university professors have a moderate level of DCUP taking into account the DigCompEdu framework.

All the studies underline that in order to face this problem, it is necessary to offer lifelong training to university professors in order to develop or improve their DC. Therefore, several authors advocate for continuous training in terms of DC to take full advantage of digital tools, since they are in continuous evolution (Alexander et al., 2019; Arruti et al., 2020; Cabero-Almenara et al., 2020; Cabero-Almenara \& Llorente-Cejudo, 2020; Ramírez-Montoya, 2020).

Finally, the main limitations are presented. In the first phase of the review many researchers focused on the DC of other educational level $34,1 \%$ and university students $30,2 \%$, and these studies were therefore discarded. Furthermore, the relative lack of literature focused on higher education, the variety of frameworks and dimensions that make up this competence, as well as the predominance of results biased by elements of self-perception, has meant that the present literature review, although it has followed a systematic and rigorous process of analysis, has not been able to go beyond a descriptive and integrated examination of the literature.

It should be stressed that the European Commission considers DCUP very important. This is confirmed by the publication of DigCompEdu framework in 2017 and by the DigCompEdu Check-In self-assessment questionnaire in 2019, which was placed in experimentation period with EU teachers the same year. However, it was not until 2020, when different university researchers used the self-assessment questionnaire in diverse fields (EU SCIENCE HUB, 2021). Therefore, currently there are not enough studies that investigate the DCUP using this tool. Similarly, it has to be stressed the importance of carrying out more research oriented to DCUP using the DigCompEdu CheckIn self-assessment questionnaire. In that case, it could be easier to respond to the different needs that university professors may have when facing technological issues. Therefore, it is necessary to adopt and apply the DigCompEdu Check-In self-assessment questionnaire in the university society, for the unification of DC. In this way, different researchers could be evaluated and assessed together in order to create equivalent training actions in the whole university environment.

Another future challenge would be to unify concepts in order to create a single term to refer to the DCUP. Therefore, it is difficult to include all the literature that addresses this topic, since there are several terms that refer to this area. Therefore, in future research, new names could be included in the review and the number of researchers could be extended to avoid possible biases, such as: DigompEdu, digital competence, teachers' professional competences and teachers' pedagogical competences. It is also important to highlight the large number of articles analysed from South America 50\%.

Similarly, an important future line of work would be to explore in future studies the possibility of using meta-analysis techniques to enrich and give statistical validity to the results. Moreover, in order to obtain a wider perspective, it would be advisable to go deeper into the analysis of this competence through qualitative research methods. In this sense, this study is part of a research in which, in the future, it will continue to further analyse the DCUP.

\section{References}

Adisa, R., Adisa, M., Usman, T., \& Barau, A. (2018). A study of Computer-based ICT Competency in the Social science Subsector of the Nigerian Higher Education System. [2018 21 ${ }^{\text {st }}$ Saudi Computer-Society National Computer Conference]. Riyadh, Saudi Arabia. https://bit.ly/3pLcsnf

Alexander, B., Ashford-Rowe, K., Barajas-Murphy, N., Dobbin, G., Knott, J., McCormack, M., Pomerantz, J., Seilhamer, R., \& Weber. N. (2019). EDUCAUSE Horizon Report: 2019 Higher Education Edition. EDUCAUSE. https://bit.ly/3sqSznj

Allas, R., Leijen, A., \& Toom, A. (2017). Supporting the construction of teacher's practical knowledge through different interactive formats of oral reflection and written reflection. Scandinavian Journal of Educational Research, 61, 600-615. https://doi. org/10.1080/00313831.2016.1172504

Amador, L. V., Cárdenas-Rodríguez, R., \& Terrón-Caro, T. (2017). Introducción: Innovación docente en el ámbito de la universidad. Revista Humanides, (31), 11-15. https://doi.org/10.5944/ rdh.31.2017.19070

Ardıç, Ö., \& Çiftçi, H. (2019). ICT competence and needs of Turkish EFL instructors: The role of gender, institution and experience. Eurasian Journal of Applied Linguistics, 5(1), 153-173. https://doi.org/10.32601/ejal.543791

Arruti, A., Paños-Castro, J., \& Korres, O. (2020). Análisis de contenido de la competencia digital en distintos marcos legislativos. Aloma, 38(2), 149-156. https://bit.ly/3dEaL8B

Aslan, A., \& Zhu, C. (2015). Pre-Servide Teachers' Perceptions of ICT Integration in Teacher Education in Turkey. The Turkish Online Journal of Educational Technology, 14(3), 97-110. https:// bit.ly/3bvgJ97

Barrera, A., Rodríguez, A. A., \& Otalára, J. E. (2018). ICT Skills in University Teachers, the Knowledge, Use and Pedagogical Appropiation of These Technologies. In Uden, L.; Liberona, D.; Ristevej, J. Learning Techonology for Education Challenges. LTEC, Springer: Cham, Switzerland. http://bit.ly/2NwjJKG 
Barrios, M., Pachón, C., Rodríguez, L., Lugo, E., Acurero, M., \& Henao, A. (2018). Perfil del profesor del programa de fisioterapia en torno a las competencias en tecnologías de la información y la comunicación. Revista Espacios, 39(52), 2. https:// bit.ly/3bCWXJ8

Barroso, J., Matos, V., \& Aguilar, S. (2019). Análisis de los recursos, usos y competencias tecnológicas del profesorado universitario para comprender y mejorar el proceso de aprendizaje del alumnado. Revista Iberoamericana de Educación, 80(1), 193-217. https://doi.org/10.35362/rie8013466

Bearman, M., Smith, C. D., Carbone, A., Slade, S., Baik, C., Hughes-Warrington, M., \& Neumann, D. L. (2012). Systematic review methodology in higher education. Higher Education Research and Development, 31(5), 625-640. https://doi.org/10.10 80/07294360.2012.702735

Beauchamp, C. (2015). Reflection in teacher education: Issues emerging from a review of current literature. Reflective Practice, 16(1), 123-141. https://doi.org/10.1080/14623943.2014.982 525

Bond, M., Marin, V. I., Dolch, C., Bedenlier, S. \& Zawacki-Richter, O. (2018). Digital transformation in German Higher Education: Student and teacher perceptions and usage of digital media. International Journal of Educational Technology in Higher Education, 15(48). https://doi.org/10.1186/s41239-018-0130-1

Bossolasco, M., \& Chiecher, A. (2015). Competencias docentes para enseñar en entornos mediados. Un ranking desde la perspectiva de un grupo de docentes universitarios. Virtualidad, Educación y Ciencia, 6(10), 38-53. http://bit.ly/2ZHGttt

Brito, J. G., \& Rivero, M. E. (2014). El proceso de producción de la construcción de ambientes virtuales de enseñanza, aprendizaje y comunicación: indicadores para evaluar la calidad. Virtualidad, Educación y Ciencia, (8), 18-28. http://bit.ly/2ZJdEgk

Brugia, M., \& Zukersteinova, A. (2019). Continuing vocational training in EU enterprises. Publications Office of the European Union. https://bit.ly/2T8R8On

Cabero, J., \& Barroso, J. (2016). ICT teacher training: a view of the TRACK model/ Formación del profesorado en ICT: una visión del modelo TRACK. Culture E Education, 28(3), 633663. https://doi.org/10.1080/11356405.2016.1203526

Cabero-Almenara, J., Barroso-Osuna, J., Gutiérrez-Castillo, J. J., Palacios-Rodríguez, A. (2021). The Teaching Digital Competence of Health Sciences Teachers. A Study at Andalusian Universities (Spain). International Journal of Environmental Research and Public Health, 18, 1-13. https://doi.org/10.3390/ ijerph18052552

Cabero-Almenara, J., Barroso-Osuna, J., Rodríguez-Gallego, M., \& Palacios-Rodríguez, A. (2020). La Competencia Digital Docente. El caso de las universidades andaluzas. Aula Abierta, 49(4), 363-372. https://doi.org/10.17811/rifie.49.4.2020.363-372

Cabero-Almenara, J., \& Llorente-Cejudo, C. (2020). Covid-19: transformación radical de la digitalización en las instituciones universitarias. Campus Virtuales, 9(2), 25-34. https:// bit.ly/3odAmab

Cabero-Almenara, J., \& Palacios-Rodríguez, A. (2020). Marco Europeo de Competencia Digital Docente «DigCompEdu» y cuestionario «DigCompEdu Check-In». EDMETIC, Revista de Educación Mediática y TIC, 9(1), 213-234. https://doi. org/10.21071/edmetic.v9i1.12462

Cabero, J., \& Valencia, R. (2020). Y el COVID-19 transformó al sistema educativo: reflexiones y experiencias. International Journal of Educational Research and Innovation, 15, 217-227. https://doi.org/10.46661/ijeri.5246

Caena, F., \& Redecker, C. (2019). Aligning teacher competence frameworks to 21st century challenges: The case for the Eu- ropean Digital Competence Framework for Educators (DigCompEdu). European Journal of Education, 54(3), 356-369. https://doi.org/10.1111/ejed.12345

Castañeda, L., \& Adell, J. (2013). Entornos Personales de Aprendizaje: claves para el ecosistema educativo en red. Marfil.

Cejas-León, R., \& Navío, A. (2018). Formación en TIC del profesorado universitario. Factores que influyen en la transferencia a la función docente. Profesorado, 22(3), 271-293. https:// doi.org/10.30827/profesorado.v22i3.8002

Chalmers, T. C., Levin, H., Sacks, H. S., Reitman, D., Berrier, J., \& Nagalingam, R. (1987) Metaanalysis of clinical trials as a scientific discpline. I: Control of bias and comparison with large co-operative trials. Statistics in Medicine, 6, 733-744. https:// bit.ly/3pMUJvE

Claro, M., Salinas, A., Cabello-Hutt, T., San Martín, E., Preiss, D. D., Valenzuela, S., \& Jara, I. (2018). Teaching in a Digital Environment (TIDE): Defining and measuring teachers' capacity to develop students' digital information and communication skills. Computers $\mathcal{E}$ Education, 121, June, 162-174. https://doi. org/10.1016/j.compedu.2018.03.001

Council of the European Union (2003). Conclusiones de la Mesa, Consejo Europeo de Bruselas de 20 y 21 de marzo de 2003. Publications Office of the Eruopean Union.

Dieguez, T. (2020). Systemic Approach to Quality Enhancement and Competitiveness in Higher Education. In Sony, M., Karingada, K.T., \& Baporikar, N. (Eds.) Quality Management Implementation in Higher Education: Practices, Models, and Case Studies. (pp. 48-71). IGI Global Publisher of Timely Knowledge. https://amzn.to/2NSDxaK

EU SCIENCE HUB (2021). Self-reflection. https://bit.ly/3oDIOus

Evans, J., \& Benefield, P. (2001). Systematic reviews of educational research: Does the medical method fit? British Educational Research Journal, 27, 527-541. https://doi. org/10.1080/01411920120095717

Ferrari, A. (2012). Digital Competence in Practice: An Analysis of Frameworks. JRC Technical Reports. Publications Office of the European Union.

Ferrari, A. (2013). DIGCOMP: A Framework for Developing and Understanding Digital Competence in Europe. JRC Technical Reports. Publications Office of the European Union.

Ferreira, C., \& Morán, M. A. (2011). La responsabilidad social corporativa (RSC) en las bases de datos Scopus y Wos (estudio bibliométrico). Asociación de Educación e Investigación en Ciencia de la Información de Iberoamérica y el Caribe, 1(4), 141160. http://bit.ly/2NQTqOX

Fraile, M., Peñalva-Vélez, A., Mendióroz-Lacambra, A. (2018). Development of Digital Competence in Secondary Education Teachers' Training. Education Science, 8(3), 104. https://doi. org/10.3390/educsci8030104

García-Peñalvo, F. J., \& Corell, A. (2020). La COVID-19: ¿enzima de la transformación digital de la docencia o reflejo de una crisis metodológica y competencial en la educación superior? Campus Virtual, 9(2), 83-98. http://bit.ly/3dFYz7y

García-Peñalvo, F. J., Corell, A., Abella-García, V., \& Grande, M. (2020). La evaluación online en la educación superior en tiempos de la COVID-19. Education in the Knowledge Society, 26. https://doi.org/10.14201/eks.23086

Gómez, J. (ed.) (2017). UNIVERSITIC 2017. Análisis de las TIC en las Universidades Españolas. Crue Universidades Españolas. http://bit.ly/37BveqX

González, M., Marco, E., \& Medina, T. (2020). Informe de iniciativas y herramientas de evaluación online universitaria en el contexto del Covid-19. Madrid, España: Ministerio de Universidades. https://bit.ly/3j9CzES 
Gough, D. (2007). Weight of evidence: A framework for the appraisal of the quality and relevance of evidence. Research $\mathrm{Pa}$ pers in Education, 22(2), 213-228. https://doi-org.proxy-oceano.deusto.es/10.1080/02671520701296189

Gough, D., Oliver, S., \& Thomas, J. (2012). An introduction to Systematic Reviews. SAGE Publications. http://amzn.to/3unR7DL

Gough, D., Oliver, S., Thomas, J., \& Hobbs, A. (2013). Learning from research: systematic reviews for informing policy decisions. Alliance for Useful Evidence. https://bit.ly/3kglura

Grande-de-Prado, M., García-Peñalvo, F. J., Corell, A., \& Abella-García, V. (2021). Evaluación en Educación Superior durante la pandemia de la COVID-19. Campus Virtuales, 10(1), 49-58. https://bit.ly/2TZKE48

Grinsztajn, F., Szteinberg, R., Sanchez, G., Mangas, J., \& Vaccaro, M. (2019). Culturas digitales y experiencias pedagógicas. Proyecto Integral de Inclusión Digital en la FCV-UBA como política institucional. Revista Iberoamericana de Tecnología en Educación y Educación en Tecnología, (23), 22-30. https://doi. org/10.24215/18509959.23.e03

Habibi, A., Razak, R. A., Yusop, F. D., \& Mukminin, A. (2019). Preparing Future EFL Teachers for Effective Technology Integration: What do Teacher Educators say? Asian EFL Journal. 21, 9-30. https://bit.ly/3bwiiUl

Heitinka, M., Voogtb, J., Van Braakc, J., \& Fisserd, P. (2016). Teachers' professional reasoning about their pedagogical use of technology. Computers $\mathcal{E}$ Education 101, 70-83. https://doi. org/10.1016/j.compedu.2016.05.009

Henning, C., Rozo, H., \& Segovia, Y. (2016). Training professors in ICT: Personal learning environments. A grounded theory research study. Je-LKS, 12(1), 39-52. https://bit.ly/3kswCBz

Hidalgo-Durán, G. (2019). Desarrollo de competencias tecnológicas: reto fundamental para los profesores universitarios costarricenses. Revista electrónica calidad en la educación superior, 10(2), 34-52. https://doi.org/10.22458/caes.v10i2.1924

Ilomaki, L., Paavola, S., Lakkala, M., \& Kantosalo, A. (2016). Digital competence an emergent boundary concept for policy and educational research. Education and Information Technologies, 21(3), 655-679. 10.1007/s10639-014-9346-4

Inan, F. A., \& Lowther, D. L. (2010). Factors Affecting Technology Integration in K-12 Classrooms: A Path Model. Educational Technology Research and Development, 58, 137-154. https://doi. org/10.1007/s11423-009-9132-y

INTEF. (2017). Marco Común de Competencia Digital Docente. INTEF. https://bit.ly/3bvLVFf

Izquierdo, J., de la Cruz-Villegas, V., Aquino-Zúñiga, S. P., Sandoval-Caraveo, M. C., \& García-Martínez, V. (2017). La enseñanza de lenguas extranjeras y el empleo de las TIC en las escuelas secundarias públicas. Comunicar, 25, 33-41. https:// doi.org/10.3916/C50-2017-03

Kaçaniku, F., Gjelaj, M., \& Saqipi, B. (2019). Context guided instruction to develop reflection competence of education professionals, Review of Education, Pedagogy, and Cultural Studies, 41, 48-67. https://doi.org/10.1080/10714413.2019.1629813

Lane, R., McMaster, H., Adnum, J., \& Cavanagh, M. (2014). Quality reflective practice in teacher education: A journey towards shared understanding. Reflective Practice, 15(4), 481494. https://doi.org/10.1080/14623943.2014.900022

Levis, D. (2011). Redes Educativas 2.1. Medios sociales, entornos colaborativos y procesos de enseñanza y aprendizaje. Revista de Universidad y Sociedad del Conocimiento, 8, 7-24. http://bit. ly/2NrfHmO

Liu, K. (2015). Critical reflection as a framework for transformative learning in teacher education. Educational Review, 67(2), 135-157. https://doi.org/10.1080/00131911.2013.839546
Lucas, M., Bem-Haja, P., Siddiq, F., Moreira, A., Redecker, C. (2021). The relation between in-service teachers' digital competence and personal and contextual factors: What matters most? Computers \& Education, 160. https://doi.org/10.1016/j. compedu.2020.104052

Lyubashits, V., Shirshov, A., Lopukhinskiy, L., Bondareva, T., Khizbullin, F., \& Stratonova, L. (2016). Psychological Bases of Formation of Key Economical Information Technology Specialist Compentencies of Higher Education. International Review of Management and Marketing, 6(1), 114-118. http://bit. ly/37Ga5M5

Mirabal, A. R., Gómez, M. G., \& González, L. A. (2015). Uso de la plataforma Moodle como apoyo a la docencia presencial universitaria. Edmetic, 4, 133-155. https://doi.org/10.21071/ edmetic.v4i1.2903

Moher, D., Liberati, A., Tetzlaff, J., Altman, D. G., \& The PRISMA Group. (2009). Preferred reporting items for systematic reviews and meta-analyses: the PRISMA statement. PLoS Med, 6(7), 1-9. https://doi.org/10.1371/journal.pmed.1000097

Montoya, N. E., \& González, E. V. (2019). Competencias TIC en docentes de nivel técnico y tecnológico. Un estudio de caso en un centro de formación del SENA. Revista Virtual Universidad Católica del Norte, (58), 74-95. http://bit.ly/2ZFHIcK

Montoya, N. E., Mosquera, S. P., Pérez, M. C., \& Arroyave, D. I. (2018). Competencias TIC del docente siglo XXI en educación superior. Revista Espacios, 39(53), 3. https://bit.ly/37IQXx0

Morales, K. A., \& Aguado, E. (2010). La legitimación de la Ciencia social en las bases de datos científicas más importantes para América Latina. Revista de estudios Latinoamericanos, (51) 159-188. https://bit.ly/3usJKv1

Nakaznyi, M., Sorokina, L., Romaniukha, M., \& Voronova, Z. (2016). The Use of ICTS in Ukrainian Technical Universitites. [DIVAI 2016 11th international scientific conference on Distance Learning in Applied Informatics]. Sturovo, Slovakia. https:// bit.ly/3khCCg9

Noskova, T., Pavlova, T., Yakovleva, O., Morze, N., Cubo-Delgado, S., \& Alonso-Díaz, L. (2019). The Use of ICT Tools by Academic Teachers in the International Comparative Context. [Conference: XIV International Conference New Educational Strategies in Modern Information Space]. Saint-Petersburg, Russia. https://bit.ly/3kjY4RU

Parada, S., \& Pluvinage, F. (2014). Reflexiones de profesores de matemáticas sobre aspectos relacionados con su pensamiento didáctico. Revista Latinoamericana de Investigación en Matemática Educativa, 17(1), 83-113. http://bit.ly/3kgIVk4

Petelin, A. S., Galustyan, O. V., Prosvetova, T. S., Petelina, E. A., \& Ryzhenkov, A. Y. (2019). Application of Educational Games for Formation and Development of ICT Competence of Teachers. International Journal of Emerging Technologies in Learning, 14(15), 193-201. https://doi.org/10.3991/ijet. v14i15.10572

Pochulu, M., Font, V., \& Rodríguez, M. (2016). Desarrollo de la competencia en análisis didáctico de formadores de futuros profesores de matemática a través del diseño de tareas. Revista Latinoamericana de Investigación en Matemática Educativa 19(1), 71-98. http://bit.ly/3sfOYYQ

Ramírez-Montoya, M. S. (2020). Transformación digital e innovación educativa en Latinoamérica en el marco del CoVId-19. Campus Virtuales, 9(2), 123-139. https://bit.ly/3a0uiwz

Redecker, C., \& Punie, Y. (2017). Digital Competence of Educators: DigCompEdu. Publications Office of the European Union. http://bit.ly/39yohbE

Rengifo-Millán, M. (2015). La globalización de la sociedad del conocimiento y la transformación universitaria. Revista Lati- 
noamericana de Ciencias Sociales, Niñez y Juventud, 13(2), 809822. https://bit.ly/3soUvfI

Ríos, J. M., Gómez, E. R., \& Rojas, M. P. (2018). Valoración de competencias TIC del profesorado universitario: Un caso en Chile. Pixel-Bit, (52), 55-65. https://doi.org/10.12795/pixelbit.2018.i52.04

Rodríguez, C., \& Del Carmen, E. (2019). Importancia del manejo de competencias tecnológicas en las prácticas docentes de la Universidad nacional Experimental de la Seguridad (UNES). Revista Educación, 43(1). https://doi.org/10.15517/revedu. v43i1.27120

Sandí, J. C., \& Sanz, C. V. (2020). Juegos serios para potenciar la adquisición de competencias digitales en la formación del profesorado. Revista Educación, 44, 471-489. https://doi. org/10.15517/revedu.v44i1.37228

Solis de Ovando, J., \& Jara, V. (2019). Competencia digital de docentes de ciencias de la salud de una universidad chilena. Píxel-BIT Revista de Medios y Educación, 56, 193-211. https:// doi.org/10.12795/pixelbit.2019.i56.10

Suarez-Carballo, F. (2020). La enseñanza del diseño gráfico en los grados españoles vinculados a la comunicación publicitaria: perfil del profesorado, métodos docentes y competencias tecnológicas. Grafica, 8(15), 32-42. https://doi.org/10.5565/rev/ grafica. 170
Sysoyev, P. V., \& Evstigneev, M. N. (2015). Foreign Language Teachers'Competency in Using Information and Communication Technologies. Procedia, 200, 157-161. https://doi. org/10.1016/j.sbspro.2015.08.037

Tobar, A. O. (2017). Índice de competencias TIC en docentes de educación superior. Campus Virtuales, 6(2), 113-125. https:// bit.ly/2ZPeyrr

UNESCO. (2015). International Conference on ICT and Post-2015 Education: Seize Digital Opportunities, Lead Education Transofrmation. [Conference]. UNESCO, Quindao, China. https://bit. ly/2YFmxXv

Ventayen, R. J. M. (2019). Educator's on the Application of Technological Tools in Teaching. International Journal of Scientific E Technology research, 9(1), 4210-4215. https://bit.ly/3shditm

Viloria, D., Pacheco, J., \& Hamburger, J. (2018). Competencias tecnológicas de los docentes de universidades colombianas. Revista Espacios, 39(43), 26. https://bit.ly/3bwBtxn

Zhang, Y., \& Wang, Y. (2019). Empirical Study on the Influecing Factors of ICT-TPCK in Higher Vocational Teachers in Higher Education. $20198^{\text {th }}$ International Conference of Educational Innovation through Techonoly, EITT. [Conference]. Biloxi. USA. http://bit. ly/2NC33RV 
